\title{
Congenital Disorder of Glycosylation Type Id
}

National Cancer Institute

\section{Source}

National Cancer Institute. Congenital Disorder of Glycosylation Type Id. NCI Thesaurus. Code $C 126870$.

A congenital disorder of glycosylation sub-type caused by mutation(s) in the ALG3 gene, encoding dol-P-Man:Man(5)GlcNAc(2)-PP-Dol alpha-1,3-mannosyltransferase. 